\title{
Cultural Identity and Female Representation in Indonesian Women's Magazines*
}

\author{
Intan Paramaditha
}

\begin{abstract}
Dewasa ini banyak media massa cetak diterbitkan oleh dan untuk perempuan. Majalah yang demikian lazim disebut majalah wanita. Sebagian besar majalah wanita diterbitkan oleh orang Indonesia (majalah wanita Indonesia); sebagian yang lain merupakan majalah asing yang diterbitkan di Indonesia (edisi Indonesia). Dalam tulisan ini dimuat perbandingan isi kedua kelompok majalah wanita tersebut, yang dikaitkan dengan isu tentang perempuan. Dari perbandingan, tampak bahwa isu modernitas, yang terutama diusung ntajalah wanita asing edisi Indonesia, mempengaruhi tampilan isi majalah wanita Indonesia.
\end{abstract}

Kata KunCI Cultural identity, gender, female representation, magazine.

Indonesian people have been introduced to the portrait of an ideal family since they first learned a sentence model in Bahasa Indonesia Elementary Student's Book: Bapak membaca koran dan Ibu memasak di dapur ('Father is reading the newspaper and mother is cooking in the kitchen'). Indonesian student generations - at least until those who went to the elementary school in the $80^{\prime}$ s like me - know by heart the members of this family. It consists of the father (he has no other names but 'Father') who is sitting in the living room with the newspaper in his hand, his wife-a woman usually illustrated in Javanese traditional kebaya - who is either sewing or cooking, their children: Budi, Tuti and Sudin. The 80's was the age where Kartini Day had already been made famous by the New Order government as "Indonesian women's emancipation day". At the same time, the traditional depiction of gender roles is still (intentionally) preserved based on the interest of Indonesian patriarchal and political system: men as the center and women as the supporters helping them maintain their position. ${ }^{* *}$ The result of this

\footnotetext{
- Presented at the Indonesia International Conference of Cultural Studies, Trawas, 3-5 February 2003, and has been revised and edited for this publishment.

" One of the examples is the establishment of women's organization Dharma Wanita which positions housewives as the supporters of their husbands' activities in politics (e.g. in organizing campaigns). Details can be seen in Rudiah Primariantari's "Negara Birokrat dan Ibu (Bapak) Pejabat" (Beaurocratic Country and Executive Wives) in Primariantari et.al.eds. Perempuan dan Politik Tubuh Fantastis (Women and Fantastic Body Politics) (Yogyakarta: Kanisius, 1998), p. 50.
} 
contradiction is that women may have a career but everything around them, including the media, will always remind them of their 'obligations' in the domestic realm, the place where they belong.

If men, like the father in the Elementary Student's Book, were encouraged to read the newspaper to be constantly aware of the actual news and to polish their ability to analyze, women were offered magazines suitable to their 'needs'. During the 80's Indonesian women's magazines kept representing images of women as "The Other" - using de Beauvoir's term, the one "differentiated from men" in the patriarchal system (Segal 1999: 40) - with their own isolated world. Women were introduced to recipes, sewing patterns, ways to take advantages of natural resources and other articles that would drive them to their 'royal seats' behind closed doors. News and stories were presented in a completely different angle. Articles appeared in women's magazines were mainly about how people struggle with their hard lives (e.g. "A Politician's Wife On The Deathbed of Her Husband", "A Beautiful Celebrity Facing Breast Cancer"). Hearttouching stories, yet not thought-provoking. Women are thought to be the creatures of feeling rather than rational beings. These kinds of articles create a gap between them and men's world and thus make them lose contact with reality.

The 90's witnessed women's boredom of what was in the store for them. More and more women felt the urge to strive for goals like their male counterparts. Magazines providing information of how to take advantages of traditional spices were not considered up to date. Being smart enough in observing the market, Cosmopolitan made its first breakthrough in Indonesia. Its first issue in 1997 threatened other women's magazines that had existed before. The label bought by Higina (taken over later by MRA Group) tried to present an image of a modern woman with "Fun, Fearless Female" motto - the kind of woman who can cross all boundaries, including the line between the domestic and the public. Cosmo was even brave enough to talk about sex in great details with daring pictures as illustrations. This was something new in Indonesia, where sex used to be a taboo subject to be discussed openly among decent women. It then turned out that Cosmo was not rejected. It made Indonesian women feel comfortable to be bold and the eagerness to talk about sex was soon perceived in a different way: it became a signifier of Western feminism offering the notion of women's determination.

Cosmo has definitely succeeded. In Jakarta, it has taken over the position of local magazine Femina as the most widely read media for women. Its accomplishment evokes the idea that the Western values are the answers to the Indonesian modern women's demands. In the minds of local women, the image of Western woman is sexier, smarter, more active and of course, much more desirable than themselves: the submissive and the traditional. This can be clearly seen as Cosmo's breakthrough was quickly followed by other international labels such as Harper's Bazaar from the U.S. and Female and Her World from Singapore (plus many more import magazines in the 
upcoming years, according to a strong rumor among the people working in the media business).

One thing that we can infer is that the demand for such magazines reflects Indonesian women's need for a more progressive reading material that cannot be provided by old-fashioned local magazines. The contents of these franchised magazines are basically the same. They explore more on the career and (much) more on sex. There are some differences, though, in the way women are represented in these magazines. In each of them, certain representations are considered more ideal than the others. By studying three magazines, this paper will examine the different representations as a result of different cultural background.

\section{Intersection Between Gender and Culture}

Three leading women's magazines - at least in Jakarta-which are going to be compared here are Femina, Female Indonesia and Cosmopolitan. Femina is originally Indonesian, known as the pioneer of women's magazines since the early 80's. Based on its background, we will see how the ideal woman is represented through the eyes of the dominant Indonesian culture. Female and Cosmopolitan, despite the fact that both are imported, issued originally in English and both have undergone some changes for local contents, still reflect two different yet intertwined cultures. Cosmopolitan is from the United States, whereas Female - though has adapted many of the Western values - is published in Singapore. We will see the kinds of women representation when the genuinely Western Cosmopolitan and the 'more sophisticated' Asian Female are translated into the Indonesian culture.

To analyze this problem we need to have an approach which Sara Ahmed calls "cultural intersections". The term refers to the connection between different representations and issues of gender, race and colonialism. Ahmed starts her point from Edward Said's concept of Orientalism. According to Said, East and West are constructed by the Europeans. Documents like novels, journals and travel writings create imaginary boundaries between the two. Although the colonization of European empires is over, the media still have the roles in depicting the binary opposition between the West-including all stereotypes associated with it, such as assertiveness and rationality - and what is not West with its less superior traits. In a similar way, Ahmed (1996: 136-137) sees that they serve as a protection to maintain the colonizer's hegemony:

colonial situations are maintained through representations that privilege the interests and values of the imperial or colonial centre. Cultural representation participated in the colonial process whereby the colonizing power (example, the British empire) was seen as the source of civilization and progress...

Nevertheless, how do we perceive the boundaries between East and West in the age of globalization where, as people always say, the world is becoming smaller? According to Wilson and Dissanayake (1996: 1), cultural production and national representation become 'more globalized (unified 
around dynamics of capitalogic moving across borders)' and, at the same time 'more localized (fragmented into contestatory enclaves of difference, coalition, and resistance)'. The penetration of international labels from technology to women's magazines does not diminish the imaginary boundaries; instead, they exist in the form of images. Ahmed suggests there is even a "contestation", which means that representations of women from different culture reflect contradictory and antagonistic relations of power. Therefore, based on the meeting point between gender and cultural identity, I will try to see how boundaries - either Nation boundaries or East and West binarism-appear in the images of Indonesian women's magazines.

\section{Femina: Negotiating with Tradition and Modernity}

Before Cosmo and other franchised magazines hit the Indonesian market, there were only Kartini, Sarinah, Mahkota and Femina. Born in the hands of university graduates (Widarti Gunawan studied Indonesian Literature at the University of Indonesia and Pia Alisjahbana was active in the university's American Studies Center), Femina was undeniably the most progressive among the others. There are more articles about working women and even the makeup tips are given not only to please husbands, but to look 'professional' in the office. I remember in the 80's my working mother would buy this magazine twice a month while my old-fashioned grandmother was happier when she brought home Kartini. Glancing at Femina in the year of 2003, however, people will quickly say that it looks more conservative than other new magazines. Not many realize that apart from its not-so-sophisticated design and its wavering effort to look fresh, Femina is trying hard to conform both to modernity and the tradition.

To be able to compete with rapid, big fat fashion and beauty information of the new magazines, Femina also tries to cover the latest global fashion trend. This is a part of Femina's fashion section called "Ekspresi Mode Dunia" (The World's Fashion Expression). There we can see a picture of an Indonesian celebrity, Maudy Koesnaedi, wearing a similar dress to that worn by a white model (look at the box on the left). Maudy stands in front of a gate with European style which serves as a perfect background for the dress designed by Elspeth Gibson, a fashion designer from London. Nevertheless, if we look closer, there is a difference between Gibson's design and its Indonesian version. The original has a low cut neckline, while the one worn by Maudy covers the chest almost entirely. Besides that, the original length - which is above the knees-is transformed into more conventional. This is how Femina deals with modernity. It borrows from the West, but translates the cultural product into the Indonesian context. At the same time, this edition also gives a sewing pattern as a bonus. The readers therefore can make themselves clothes designed by the international designers. In presenting the ideal Indonesian woman's image, Femina tries to avoid the Western consumerism lifestyle while at the same time keeps the domestic ability - that Indonesian housewives are supposed to be proud of - in the foreground. 
The same case of translating culture can be found in an article about Madonna, a Western icon who is often regarded too liberal for Indonesian culture. Instead of representing the usual Madonna as "the material girl" who made controversial maneuvers by commercializing her sexuality in the 80 's and 90 's, the article highlights more on the 'positive' side of her: "she likes to show her body, but she forbids her daughter from watching television. She's a tough, independent woman, but still feminine" Wilson and Dissanayake (1996: 12). Madonna's wild side is put out of sight, just like a gown from London which is conventionalized to be adjusted for the Eastern culture.

Another representation of the ideal Indonesian woman's image can be seen in articles like "Mentimun, Bukan Cuma untuk Lalap" (Cucumber, Not Only For Salad) Wilson and Dissanayake (1996: 107). Women are encouraged to take advantages of natural resources in taking care of their health and beauty. It reminds us of the ancient tradition of Indonesian women which is very nurturing; they take care of their family's health with herbs and spices found in the backyard. Besides emphasizing on the nurturing characteristics, Femina wants to convey that Indonesian tradition can go together with, if not challenge, the Western modern technology.

A survey by Ogilvy shows that, compared to other Asian families, Indonesian people believe that behind every successful family there is always be a mother who can cook (Femina, No. 12/XXVIII, 30 March-5 April 2000, p. 9.). Realizing the importance of women's knowledge on nutritions and how to serve them in the dining table, Femina makes "Dapur" (Kitchen) - a very traditional symbol of the feminine realm-as one of the columns carefully managed. Recipes (from Femina's cooking team and those sent by the reader) and cooking tips take more than 4 pages. As if not getting enough space, sometimes articles about food appear in the feature section. As a feature article, Femina discusses the problem of balanced nutrition which is difficult to achieve because women today have various activities. Ogilvy's research result was made as reference to reveal that modern food does not guarantee good nutritional values, so it would be better for mothers to return to the traditional way of cooking using the natural ingredients. Femina does not question why it is the mother who has to be fully aware of the family's good diet and not the father. This article seems to remind women who work outside their homes that they should not forget their real 'duties' to their families.

Femina certainly realizes that modern women's activities are not only limited in the domestic area, as written in the Editor's note: "Because of economical reasons, a lot of Asian women nowadays choose to work outside their homes (Femina, No. 12/XXVIII, 30 March-5 April 2000, p. 9)". Although the reasons why women work outside are considered merely for financial reasons - not a self-defining act-at least Femina does not close its eyes from women's movement today. That is why we can find regular columns like "Info Kita" (Our Info) talking about every aspect in women's lives, including career. Problems of working women are often discussed, 
but usually they are still related to family matters. Article entitled "It's not easy to be a Supermom" depicts a woman's dilemma as both a working woman and a mother who is responsible to prepare their children to be independent in the future (Femina, No. 12/XXVIII, 30 March -5 April 2000, p. 57). The picture of a mother and a child in it emphasizes the idea that women the motherhood fate is something given, not a choice. The doubleroles or Supermom concept created by patriarchy is legitimized by Femina. The magazine offers the way to be a Supermom without deconstructing why women (not men) should face such a dilemma without being given more options in their lives. Women's full responsibility to their children shows from a number of advertisements for children, from Happy Meal's package in Mc Donald's to Biolysin, children's cough medicine.

From the discussion above we can infer that Femina does not indicate an extreme rejection to the Indonesian patriarchal culture that ascribes women with traditional roles. It accepts the conventional values but also tries to negotiate regarding that a lot of women choose to have a career. The Supermom concept is Femina's ultimate destination: women can achieve their goals outside without neglecting their 'given' roles to take care of their husband and children.

\section{Female, Between The Two Worlds}

Unlike Femina with its philosophy of making the most of our traditional heritage, Female believes much more in modernity. Singapore, the place where it comes from, is seen as the most favorite shopping spot for the Indonesian upper class society. This is due to the fact that the country receives more information and products much faster than Indonesia. Even though geographically Singapore is very near, it can be considered as 'the more global sister' of Indonesia. That is why Female provides a more modern environment for women than local magazines like Femina, just as it aims its target market: "Modern and Sophisticated Woman". Here women's career is explored more in columns like "Work" and "Office Politics". Women are given advice in financial matters in the "Money" column. If there is almost no space for technology in Femina, every month Female readers can get to know the latest features from mobile phone to Palm PDA by reading "Gadget Girl".

Nevertheless, in this more modern atmosphere, we can still sense some Eastern values. Although Female reveals the multidimensional lives of modern women, the "motherhood" theme which we find dominant in Femina still exists. To reflect the desire of an Eastern woman to become a mother and build a family, however, it appears in a much smaller portion. Motherhood is also associated with modernity. An article entitled "Bisakah Aku Hamil?" (Can I Have a Baby?) talks about the use of modern technology ("culture") as a way to be a mother ("nature") (Female Indonesia, October 2000, p. 91). Recipes still shows up, although not being explored extensively as in Femina and the way of cooking is more practical and modern. There 
are more simple, international menus; while in Femina women really have to sweat to make difficult traditional Indonesian cuisines.

Another difference between Female and Femina lays in the way they treat sexual matters. In Femina, sex appears in a small health column, usually along with an opinion of a sexologist. In Female sex becomes more fun and is not presented as merely a "health problem". There are tricks and secrets to share for women in order to enjoy sex. Despite of a greater exploration in sex, Female realizes its own identity as an Asian magazine. The illustrations, for example, are not vulgar; Female prefers drawings instead of daring photographs for sex articles.

The East-Meets-West representation hence seems to be an ideal identity. The fashion section, for example, shows its favor for traditional nuances in the modern era, like a modern kebaya for Idul Fitri (Female Indonesia, January 2001, p. 118). In Chinese New Year - celebrated both in Indonesia and Singapore-Female issues the picture of a woman in cheongsam in front of a computer to represent a harmonious combination of traditional and modern elements (Female Indonesia, February 2001, p. 57).

Up to this point we can presume that first, Female is more progressive than Femina in terms of giving more information about career, money and technology; second, it seems to have no problem with traditions. Nevertheless, how does Female actually see its Asian identity and how great is its desire to preserve the tradition along with its modern values? We can see there is an ambiguity. Although on the surface Female is quite proud with its traditionalmodern blend, it somehow sees itself as a representation of an Asian woman who-whether she likes it or not-has to carry the burden of past tradition within herself. In an article entitled "Wanita Tabu Berbicara Kotor?" (Women Cannot Speak Dirty?), Female positions itself as truly Asian but feels the need to be free from its restricting values:

\footnotetext{
"If men can use dirty language to express their feelings, I don't understand why women can't do the same. We live in a double-standard world. This is always be a man's world... Asian people still detest women who express themselves with expletives in the conversation." (Female Indonesia, December 2000, p. 104-105)
}

This "double standard society" is what limits the movement of Asian women. In this article the writer mentions that women who are sent abroad to receive "higher education" and "freed themselves of traditional values" do not hesitate to use dirty words. Talking dirty here can be interpreted as a symbol of freedom. The kind of freedom that cannot be found in Asia, but in America, the place that the article refers as "The Land of Freedom". The thought that women are unable to speak their minds within the cultural boundary reminds us of what Said (1978: 244) states: We are left at the end with a sense of the pathetic distance that separates 'us' from an Orient destined to bear its foreignness as a mark of its permanent estrangement from the West. Female represents Asian women's alienated feeling because, despite of their modernity, they cannot be completely like their white sisters. They want to identify themselves with. Western women who are considered blessed with education, courage and freedom. 
The way Asian women see the West and themselves is also reflected on the beauty columns. In an article entitled "Lima Wajah Berbeda Bangsa" (Five Faces of Different Nations), Female seems to be eager to discover Singapore's 'wealthy resources' as a multicultural country (Female Indonesia, August 2000, p. 60). Chinese, Indian, Malay, Euroasian, and white women appear together in the article. The magazine wants to communicate the message that women with different ethnic and racial backgrounds are equally beautiful due to their individual uniqueness. Nevertheless, this article has a very different tone with what turns up next: "Terbang ke Bulan" (Flying to The Moon) (Female Indonesia, August 2000, p. 66). It talks about a whitening capsule which, according to the writer, has been a great obsession of Asian women: "... women in the East have been craving to have white skin. Fairness is even thought as the sign of beauty"(Female Indonesia, August 2000, p. 67). Bali, the place where the capsule was launched, was described as the mystical and exotic representation of the East. But the desired image resulted from using the product is not at all 'exotic'; it shows from the picture of a white woman with blonde hair and blue eyes. This contradicts the previous article which seems to appreciate different kinds of beauty.

Therefore, in this "modern and sophisticated" magazine we witness anxieties. We can see on one side the effort to value itself as truly Asian while on the other, and the inferior feeling as 'The Other'. To be always enriched with sophistication Female perceives the need to identify itself with the West. This, nonetheless, cannot be done completely because of the limitation of Eastern values.

\section{Cosmopolitan: A Real Fun Fearless Female?}

If Femina tries to settle with Indonesian tradition and Female is trapped between two cultures, this magazine-whose name was at first localized into "Kosmopolitan" and was renamed again in 2001 into the original "Cosmopolitan" - portrays a modern woman who is able to challenge all conventions. The American liberal values can be seen from bold visualization: photographs of bare skin and sexual act for sex articles. Cosmo suggests that modern women are not embarrassed to express what they want in bed. Men are not the only ones who get the privilege to initiate sex; women can also be full of initiatives. This does not only apply in sexual relationships but also in career and personal life. Women's determination issue gives way for a column where a "Fun Fearless Female", a successful local woman in her field, is appointed each month.

The modern image of woman is also reflected through technology and finance section. Women now are not alienated from technology, and this can be seen from short articles like "Cara Baru Menggunakan Teknologi" (New Ways to Use Technology) or "I.T. Girl Abad 21" (21th Century I.T. Girl). In four pages, the author talks about the advantage of technology, how to use it and features about women who work in I.T. fields (Kosmopolitan, March 2000, p. 122). This is more progressive than Female, 
which only encourages women to buy the gadgets; to become consumer without being given understanding of the technology features.

Cosmo Career and Money Talks columns are designed to help women to decide for career and financial matters. Although these are regular columns, we still find these two themes in the feature section. This indicates a lot of sides to be explored in working women's lives: how they deal with work ethics and how they should manage their own income. Compared to Female and Femina, Cosmo gives more portions for career and money.

Then how does Cosmo deal with the traditional representation of Indonesian woman who is always be depicted as 'The Queen of the Kitchen' ? Cosmo explicitly refuses the idea that the main role of women is to take care of the family. Here we cannot even find recipes (like in Female) or Kitchen column (as in Femina). If in Femina we find a lot of babies food ads, in Cosmo we will only find the masculine advertisement of Pall Mall cigarette. For Cosmo women, motherhood is only a choice, not an obligation. In "S.A.S.H.A.: Perempuan Abad 21" (S.A.S.H.A.: The 21 ${ }^{\text {st }}$ Century Woman), Cosmo reveals a conclusion from a recent survey in the U.K.: more women choose either to postpone their marriage or live as singles (Kosmopolitan, March 2000, p. 22). The SASHA values (Single, Attractive, Successful, Happy \& Affluent) reflect the Western liberal thoughts. Here we can see how Cosmo tries to identify modern Indonesian women with Western women who believe in SASHA. It gives some evidence that a lot of women in Indonesia do not feel the pressure of getting married. If they are asked when to get married, they will ask in return, "Must I?" The SASHA women are brave enough to make decisions, including to break up with a man who is too sensitive to face that his spouse can make more money.

Furthermore, Cosmo overtly declares that "The influences of the Eastern tradition and religion are still very strong, but from day to day, there are more women who open their eyes and realize that they should enjoy their lives". So we can see how Cosmo as a franchised magazine reveals a resistance of the monotonous, unattractive Indonesian identity. The tradition of the East is positioned as the barrier of happiness and progress, but women can "open their eyes" to oppose it. We can see clearly that the image of woman fighter is a bold Western woman - the kind woman idealized by Female and avoided by Femina (and if this kind of woman appears in Femina, she has to go through some filters like Madonna).

To sum up, Cosmo has defined its clear point: women who identify themselves with the West can be happier. Nonetheless, behind the image of "Fun Fearless Female", we find uneasiness. In sex, for example, although women are more confident to talk openly and discuss what they desire, they still anxiously think about men's perspectives on them. This burden can be seen from an article entitled "Payudara: Bukan Ukuran Utama" (Breasts: Size Does Not Matter"), in which Cosmo asks men questions women are eager to ask but ashamed to do it. Some of the questions are the importance of large breasts for men and whether they like breasts implant. Although the answers are quite supportive - it turns out that men are not 
troubled with size and shape - those doubtful questions show how women still depend on men to feel comfortable about themselves. There are still doubts and worries of women about themselves on whether they can fulfill the male standards. It is therefore no surprise to find columns like "Kata Si Dia" (He says) or "Opini Laki-laki" (Men's Opinion). This is very ironic, regarding the fact the woman's image Cosmo wants to present is the woman who knows what she wants. Apart from its progressive values, Cosmo is still a magazine carrying the patriarchal ideology that perceives woman's existence from the point of view of man.

\section{CONCLUSION}

We have seen different representations of women in each magazine as a result of different culture. Femina still tries to preserve the traditional image of Indonesian woman with its nurturing quality and full responsibility in the domestic sphere. Modernity is considered as Western products or the demand of globalization, but it does not have to be completely rejected. Femina wants to compromise with both worlds: the modern and the traditional. The negative impact of this approach results in the demanding multi-roles of women, which can be a burden because women have to be perfect in their identities as individuals, mothers and wives.

Meanwhile Female presents a more progressive modern woman image, but actually it sees limitation because of the Eastern culture. It tries to identify itself with the West as the representation of progress, sophistication and freedom of thought. Compared to Femina, Female's position is more likely what Sara Ahmed refers as "colonial situations". The identity of a woman portrayed in Female is an Asian woman who faces the dilemma for not being able to be thoroughly West by carrying the burden of Eastern traditions.

Cosmo represents the Western woman image, which is considered more modern by both Femina and Female. Liberal and individual values of the magazine convince the readers that they are the kind of women who can determine what they want for themselves. However, in this more sophisticated image, we see another face: the face of a woman who still cannot release herself from patriarchy. Cosmo represents a woman who can be free from the bondage of (Eastern) tradition, but at the same time most achievements are still strongly based on the point of view of men. Cosmo's success in Indonesia therefore shows two things: first, the local women's anxiety to be the "third world women" (who cannot be as bold as their Western sisters portrayed by the magazine), and second, women's inability to realize how they are still trapped in the patriarchal way of thinking. The colonialism therefore results from two sources: the so-called "pathetic distance" between East and West and the undying shadow of patriarchy.

From the discussion above we can conclude that even the magazine with the most modern representation of woman still cannot itself from the idea that woman's existence is defined by patriarchy. Although 
conventional magazines were left behind, Indonesian women still have not found reading materials that can bring them true knowledge. The notion of 'modernity' seems to fail in offering gender equality. Indonesian women need to redefine themselves; they need to understand that equality does not only mean leaving the domestic sphere. It is a realization that the selfconcept cannot be defined by other than the woman herself.

\section{REFERENCES}

Sara Ahmed (1996), "Constructions of Women and/in the Orient" in Tess Cosslett et.al. (eds), Women, Power and Resistance: An Introduction To Women's Studies. Philadelphia: Open University Press.

Cosslett, Tess, et.al.eds (1996), Women, Pozver and Resistance: An Introduction To Women's Studies. Philadelphia: Open University Press, 1996.

Female Indonesia, August 2000.

Female Indonesia, October 2000.

Female Indonesia, December 2000.

Female Indonesia, January 2001.

Female Indonesia, February 2001.

Femina, No. 12/XXVIII, 30 March-5 April 2000.

Femina, No. 02/XXIX, 11-17 January 2001.

Primariantari, et.al. eds. (1998), Perempuan dan Politik Tubuh Fantastis (Women and The Fantastic Body Politics). Yogyakarta: Penerbit Kanisius.

Kosmopolitan, Collector's Edition 2000.

Kosmopolitan, March 1999.

Kosmopolitan, March 2000.

Said, Edward (1978), Orientalism. London: Routledge and Kegan Paul.

Segal, Lynne (1999), Why Feninism. Cambridge: Polity Press.

Wilson, Rob \& Wimal Dissanayake (1996), Global Local: Cultural Production and The Transnational Imaginary. Durham \& London: Duke University Press. 